\title{
Peningkatan Kesadaran Hidup Sehat untuk Pencegahan Covid -19 melalui Cuci Tangan dan memakai Masker
}

\author{
Rahma Kusuma Dewi ${ }^{1 *}$, Nara Lintan Mega Puspita², Mayasari Putri Ardela ${ }^{3}$, Huda \\ Rohmawati $^{4}$, Siti Aminah ${ }^{5}$, Meirna Eka Fitriasnani ${ }^{6}$, Fauzia Laili ${ }^{7}$, Weni Tri Purnani ${ }^{8}$ \\ Lindha Kusumawati ${ }^{9}$, Harnida ${ }^{10}$, Nurul Istikvarini ${ }^{11}$ \\ 1,2,3,4,5 Program Studi Pendidikan Profesi Bidan, Fakultas Ilmu Kesehatan, Universitas Kadiri \\ 6,7,8,9,10 Program Studi Kebidanan S1, Fakultas Ilmu Kesehatan, Universitas Kadiri \\ *Correspondent Author: rahmakusumadewi@unik-kediri.ac.id
}

\begin{abstract}
ABSTRAK
Peningkatan kesadaran hidup sehat merupakan langkah untuk mencapai derajat kesehatan yang baik bagi setiap orang. Masyarakat di RT 16 RW 04 Desa Gogorante Kabupaten Kediri merupakan tempat yang masyarakatnya masih kurang pengetahuan dan informasi sehingga masalah kesehatan masyarakat masih menjadi masalah yang cukup besar. Selain itu akhir-akhir ini sedang terjadi pandemi virus korona yang berbahaya bagi tubuh. Sehingga sangat dibutuhkan edukasi mengenai peningkatkan kesadaran hidup sehat sebagai pencegahan covid-19 salah satunya dengan melalui cuci tangan dan memakai masker yang benar. Pengabdian ini bertujuan untuk meningkatkan pengetahuan, kesadaran, kemauan dan kemampuan masyarakat untuk meningkatkan kesadaran hidup sehat serta meningkatkan taraf kesehatan masyarakat. Metode yang digunakan adalah memberikan penyuluhan kepada 20 responden dengan tetap jaga jarak. Penyuluhan disampaikan dengan tema peningkatan kesadaran hidup sehat melalui cara cuci tangan yang benar, dan cara memakai masker yang benar. Selain itu dilakukan pembagian masker dan handsanitizer kepada warga. Hasil penyuluhan menunjukkan terdapat peningkatan yang signifikan pemahaman masyarakat tentang masalah tersebut dari $38,15 \%$ menjadi $97,35 \%$. Berdasarkan hasil ini diharapkan masyarakat dapat menerapkan pengetahuan tersebut dengan benar demi mewujudkan derajat kesehatan masyarakat yang setinggi-tingginya.
\end{abstract}

Kata Kunci: Covid-19, Cuci Tangan, Masker

Received: July 8, 2021

Revised: August 10, 2021

Accepted: September 1, 2021

This is an open-acces article distributed under the terms of the Creative Commons Attribution-ShareAlike 4.0 International License.

\section{PENDAHULUAN}

Coronavirus adalah sekelompok virus dengan struktur RNA untai tunggal. Beberapa subtipe diketahui mempengaruhi manusia, yang sebagian besar menyebabkan infeksi ringan pada saluran pernapasan bagian atas individu imunokompeten (Lu et al., 2020) (Rogers et al., 2020) (Desforges et al., 2019) (Anindyajati et al., 2021). Tanda dan gejala maupun keluhan yang sering terjadi pada pasien adalah batuk, demam, sesak napas, penurunan atau kehilangan fungsi penciuman dan lainlain (Nienhaus \& Hod, 2020).

Kasus pertama COVID-19 di Indonesia diumumkan oleh Presiden Jokowi pada 2 Maret 2020 di Jakarta (Go, 2020). Pemerintah Indonesia kemudian merekomendasikan strategi untuk mencegah penularan dengan melakukan "tiga M", yaitu: memakai masker, menjaga jarak (menjaga jarak fisik 1-1,5 m) dan mencuci tangan pakai sabun. cuci tangan pakai sabun) (Dwipayanti et al., 2021).

Cuci Tangan Pakai Sabun sebenarnya sudah dianjurkan oleh Organisasi Kesehatan Dunia 


\section{Journal of Community Engagement in Health}

http://jceh.org

https://doi.org/10.30994/jceh.v4i2.242

ISSN: 2620-3758 (print); 2620-3766 (online)

Vol. 4 No 2. Sep 2021. Page. 287-290

sebagai strategi paling efektif dan murah untuk mencegah penularan SARS CoV-2 (WHO, 2020). Sebuah studi baru-baru ini melaporkan bahwa kebersihan tangan bersama dengan tindakan perlindungan lainnya seperti memakai masker dan menghindari keramaian juga berkontribusi pada penurunan infeksi saluran pernapasan lainnya selama pandemi COVID-19(Chiu et al., 2020).

Meskipun langkah-langkah pencegahan diperkenalkan selama Pandemi COVID-19 dengan meningkatkan kepatuhan terhadap praktik kebersihan tangan, penting untuk memahami bagaimana mempertahankan praktik ini di masa pascapandemi. Tujuan dari pengabdian kepada masyarakat ini adalah untuk meningkatkan kesadaran masyarakat Desa Gogorante Kecamatan Ngasem Kabupaten Kediri tentang Pandemi COVID-19.

\section{BAHAN DAN METODE}

Pengabdian kepada masyarakat ini dilaksanakan pada masyarakat di RT 16 RW 04 Desa Gogorante Kabupaten Kediri dan dibatasi 15 orang. Peserta penyuluhan kesehatan ini sangat dibatasi pada awalnya peserta diminta mencuci tangan, mengukur suhu tubuh oleh tim PKM. Seluruh peserta yang diukur suhu tubuhnya memiliki suhu tubuh yang kurang dari $37.0^{\circ} \mathrm{C}$. Peserta tidak diijinkan untuk membuka masker atau menurunkan masker. Materi penyuluhan yang diberikan seputar COVID-19, cara cuci tangan yang benar dan penggunaan masker.

\section{HASIL}

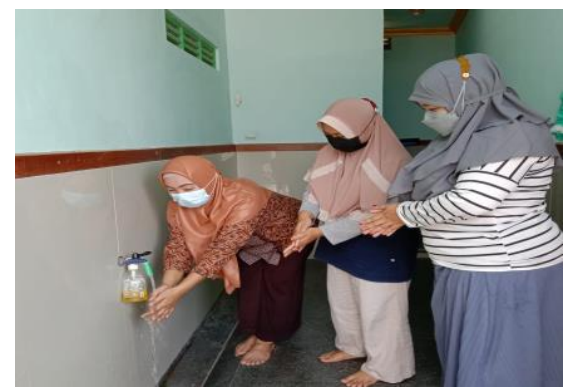

Gambar 1. Role Play Cuci Tangan

Gambar 1 menjelaskan bagaimana masyarakat diajarkan untuk mencegah penyebaran virus COVID-19 dengan simulasi cuci tangan. Simulasi cuci tangan ini dilaksanakan dengan metode enam benar. Setelah 6 kali simulasi seluruh peserta PKM dapat melaksanakan secara baik. Tim juga meminta untuk mengajarkan keluarga dirumah terkait cara mencuci tangan dengan benar.
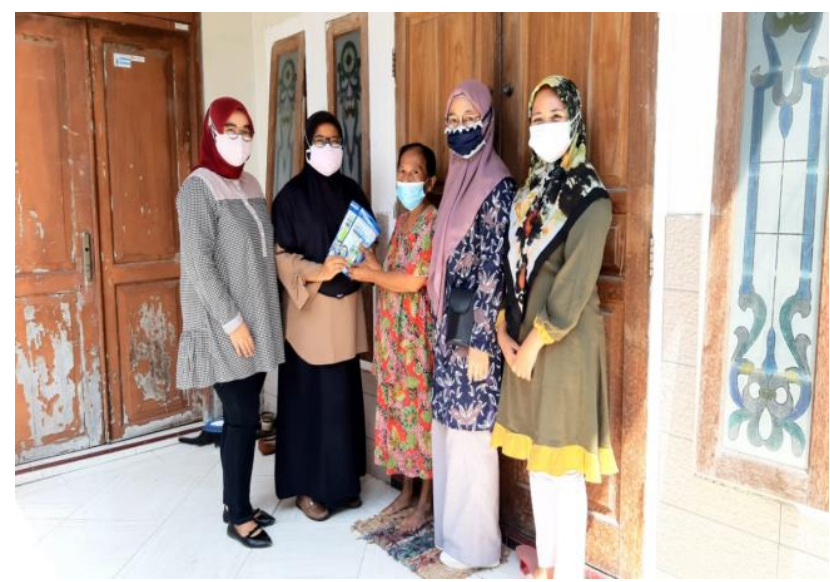

Gambar 2. Pembagian Masker

Gambar 2 Pembagian masker pada masyarakat untuk mencegah penyebaran virus COVID-19 . pembagian masker ini sebagai upaya promotif dan preventif seluruh peserta PKM agar dapat digunakan secara baik. 


\section{Journal of Community Engagement in Health}

http://jceh.org

ISSN: 2620-3758 (print); 2620-3766 (online)

https://doi.org/10.30994/jceh.v4i2.242

Vol. 4 No 2. Sep 2021. Page. 287-290

\section{PEMBAHASAN}

Peningkatkan kesadaran hidup sehat untuk mencegah covid-19 melalui cuci tangan dan memakai masker merupakan pengabdian masyarakat yang dilaksanakan di RT 16 RW 04 Desa Gogorante Kabupaten Kediri. Persiapan yang dilakukan yaitu adalah persiapan administrative dan teknis. Persiapan administrative yang dilakukan adalah ijin kepada Kepala Desa Gogorante. Persiapan teknis yaitu, Alat ukur suhu, Cuci Tangan, masker, handsanitazer.

Materi yang diberikan merupakan role play cuci tangan dengan metode 6 langkah. Peserta dan tim PKM melakukan role play bersama-sama. Role play diulangi beberapa kali hingga seluruh peserta melalukan cuci tangan 6 langkah dengan benar. Penyuluhan kesehatan dan juga role play mencuci tangan merupakan sebuah upaya untuk meningkatkan pemahaman dan juga sikap dari masyarakat bagaimana cara mencegah COVID-19. Penyuluhan ini tidak dilakukan pengukuran pre dan pos tes tetapi pemahaman diukur dengan tanya jawab dan juga role play yang telah dilaksanakan. Penyuluhan kesehatan ini tetap dilaksanakan secara offline karena keterbatasan kemampuan dari masyarakat untuk menjangkau informasi terkait COVID-19 yang tepat dan lengkap sangatlah minim apabila melalui daring. Selain itu, masih kurangnya rasa ingin tahu juga menjadi salah satu penyebab kurangnya pemahaman masyarakat terhadap COVID19.

\section{KESIMPULAN}

Kegiatan Pengabdian Kepada Masyarakat selama masa pandemi COVID-19 memiliki banyak tantangan. Namun, kegiatan penyuluhan kesehatan tentang pencegahan COVID-19 melalui cuci tangan dan pembagian masker ini mampu meningkatkan pemahaman masyarakat di Desa Gogorante.

\section{REFERENSI}

Anindyajati, G., Wiguna, T., Murtani, B. J., Christian, H., Wigantara, N. A., Putra, A. A., Hanafi, E., Minayati, K., Ismail, R. I., Kaligis, F., Savitri, A. I., Uiterwaal, C. S. P. M., \& Diatri, H. (2021). Anxiety and Its Associated Factors During the Initial Phase of the COVID-19 Pandemic in Indonesia. Frontiers in Psychiatry, 12(March), 1-10. https://doi.org/10.3389/fpsyt.2021.634585

Chiu, N.-C., Chi, H., Tai, Y.-L., Peng, C.-C., Tseng, C.-Y., Chen, C.-C., Tan, B. F., \& Lin, C.-Y. (2020). Impact of Wearing Masks, Hand Hygiene, and Social Distancing on Influenza, Enterovirus, and All-Cause Pneumonia During the Coronavirus Pandemic: Retrospective National Epidemiological Surveillance Study. Journal of Medical Internet Research, 22(8), e21257-e21257. https://doi.org/10.2196/21257

Desforges, M., Le Coupanec, A., Dubeau, P., Bourgouin, A., Lajoie, L., Dubé, M., \& Talbot, P. J. (2019). Human coronaviruses and other respiratory viruses: Underestimated opportunistic pathogens of the central nervous system? Viruses, 12(1), 1-28. https://doi.org/10.3390/v12010014

Dwipayanti, N. M. U., Lubis, D. S., \& Harjana, N. P. A. (2021). Public Perception and Hand Hygiene Behavior During COVID-19 Pandemic in Indonesia. Frontiers in Public Health, 9(May), 1-12. https://doi.org/10.3389/fpubh.2021.621800

Go, I. (2020). Distribution Map of COVID-19. sebaran (accessed October 20, 2020)

Lu, R., Zhao, X., Li, J., Niu, P., Yang, B., Wu, H., Wang, W., Song, H., Huang, B., Zhu, N., Bi, Y., Ma, X., Zhan, F., Wang, L., Hu, T., Zhou, H., Hu, Z., Zhou, W., Zhao, L., ... Tan, W. (2020). Genomic characterisation and epidemiology of 2019 novel coronavirus: implications for virus origins and receptor binding. The Lancet, 395(10224), 565-574. https://doi.org/10.1016/S01406736(20)30251-8

Nienhaus, A., \& Hod, R. (2020). COVID-19 among health workers in germany and Malaysia. International Journal of Environmental Research and Public Health, 17(13), 1-10. https://doi.org/10.3390/ijerph17134881

Rogers, J. P., Chesney, E., Oliver, D., Pollak, T. A., McGuire, P., Fusar-Poli, P., Zandi, M. S., Lewis, G., \& David, A. S. (2020). Psychiatric and neuropsychiatric presentations associated with severe coronavirus infections: a systematic review and meta-analysis with comparison to the COVID19 pandemic. The Lancet Psychiatry, 7(7), 611-627. https://doi.org/10.1016/S2215- 


\section{Journal of Community Engagement in Health}

http://jceh.org

https://doi.org/10.30994/jceh.v4i2.242

ISSN: 2620-3758 (print); 2620-3766 (online)

Vol. 4 No 2. Sep 2021. Page. 287-290

0366(20)30203-0

WHO. (2020). Water, sanitation, hygiene, and waste management for SARS-CoV-2, the virus that causes COVID-19. Interim Guidance, 29 July, 1-11.

https://www.who.int/publications/i/item/water-sanitation-hygiene-and-waste-management-forthe-covid-19-virus-interim-guidance 